\title{
11. CALPIONELLIDS FROM THE UPPER JURASSIC AND NEOCOMIAN OF DEEP SEA DRILLING PROJECT SITE 416, MOROCCAN BASIN, EASTERN NORTH ATLANTIC
}

\author{
Edith Vincent, ${ }^{1}$ Roger Lehmann, ${ }^{2}$ William V. Sliter, ${ }^{3}$ and M. Jean Westberg ${ }^{1}$
}

\section{INTRODUCTION}

A "flysch" sequence of Tithonian-Neocomian distal turbidites was continuously cored at DSDP Sites 416 and 370 , in the deep Moroccan Basin, near the foot of the continental slope, at a water depth of approximately 4200 meters (Figure 1). The sites were drilled about $2 \mathrm{~km}$ apart, during Legs 50 and 41 (Lancelot, Seibold, et al., 1978) respectively, and their stratigraphic sequences were combined (Figure 2).

A detailed lithologic description of the 740-meter Jurassic-Neocomian section (885-1624 m below sea floor; Cores 370-35 through 370-51 and Cores 416A-9 through 416A-57) is given in the Site 416 report (this volume). This series includes lithologic units VI and VII, which consist of alternations of terrigenous and carbonate-rich, thinly bedded cycles $(5-20 \mathrm{~cm}$ thick) and a minor amount of silt-mud laminites and sand layers with sharp bases and tops. The majority of these cyclic beds are turbidites, as evidenced by graded bedding, erosional bottom structures and easily identifiable, classical Bouma sequences. Unit VII (1430-1624 m; Cores 416A-37 through 416A-57) differs from unit VI by the common occurrence of hard micritic limestone in the upper part of the calciturbidite beds and of lithoclasts of calpionellid limestone in their coarse basalt parts. The calciturbidites of unit VII form a distinct population, with thicker beds than their quartzose equivalents. A typical calciturbidite consists from bottom to top of (1) quartz-bearing calcarenite whose main components are lithoclasts of micritic limestone (some with calpionellids), skeletal fragments, aptychi, ostracodes, benthic foraminifers, and calcisphaerulids; (2) parallel or crosslaminated, micritic calcisiltite to quartz siltstone, with skeletal debris, particularly thin shells, and calpionellids (generally hydrodynamically sorted in layers); (3) dark, laminated marlstone rich in dolomite(?) rhombs and rather well-preserved nannofossils; and (4) laminated, micritic limestone with some marlstone, often burrowed from the top. Figures 3 and 4 show examples of variations around this ideal sequence. A detailed discussion on vertical variations in indexes of proximity (average bed thicknesses and percentage of bed containing complete or incomplete Bouma sequence) is given in the Site 416 report (this volume; see also Price, this volume).

\footnotetext{
I Scripps Institution of Oceanography, La Jolla, California 92093.

${ }^{2}$ ESSO, EPR-E, 213 Cours Victor-Hugo, 33321 Bègles, France. 22092.
}

From an analysis of variations observed in the structure and compaction of individual turbidite sequences, Price (this volume) and Schlager (this volume) conclude that sediment came from two distinct sources to the east. The first source was offshore carbonate banks, and the second was a detrital province on the continent. The two sorts of sediments, although arriving separately, were often mixed while they were deposited in the basin by turbidity currents. Hemipelagic, aragonitic lime muds rich in calpionellids were probably deposited on the shelf between the carbonate banks and Site 416, and also on the slope, and were then partly eroded by turbidity currents which transported mud pellets and calpionellids to Site 416 .

Site 416 at the time occupied a very distal position on a deep-sea fan system. The sea floor at the site was below the CCD, at a water depth probably well in excess of 2000 meters, as indicated by arenaceous deep-water benthic foraminifers (Sliter, this volume). This indigenous foraminifer assemblage occurs only in the uppermost parts of the turbidite cycles. Other benthic foraminifers consist of transported and sorted bathyal and neritic species.

During late Kimmeridgian and Neocomian times, a widespread regression is recorded in various North Atlantic basins. While massive amounts of detrital sediments were poured into the deep Moroccan Basin, neritic and littoral sediments were deposited in sedimentary basins of southwestern Morocco. Uppermost-Jurassic and Berriasian facies in these basins include marly and dolomitic limestones with neritic faunas and floras that consist largely of calcareous algae and shallow-water benthic foraminifers. Calpionellids have been observed in the deeper part of the basins, especially in the western Haha Basin (Brun, 1962; Choubert and Faure-Muret, 1962; Viotti, 1965; Hottinger, 1966; Société Chérifienne des Pétroles, 1966).

\section{BIOSTRATIGRAPHY AND SEDIMENT ACCUMULATION RATES}

From the preceding discussion it appears that all Jurassic-Neocomian calcareous material at Sites 416/ 370 was resedimented from shallower water. Redeposition, however, was apparently penecontemporaneous, as indicated by the normal order of first occurrences of species from various fossil groups, making biostratigraphic zonation possible (Figure 5). Last occurrences of species do not appear reliable, as evidenced by common upward reworking in all fossil groups. In addition, the poor preservation of all calcareous microfossils 


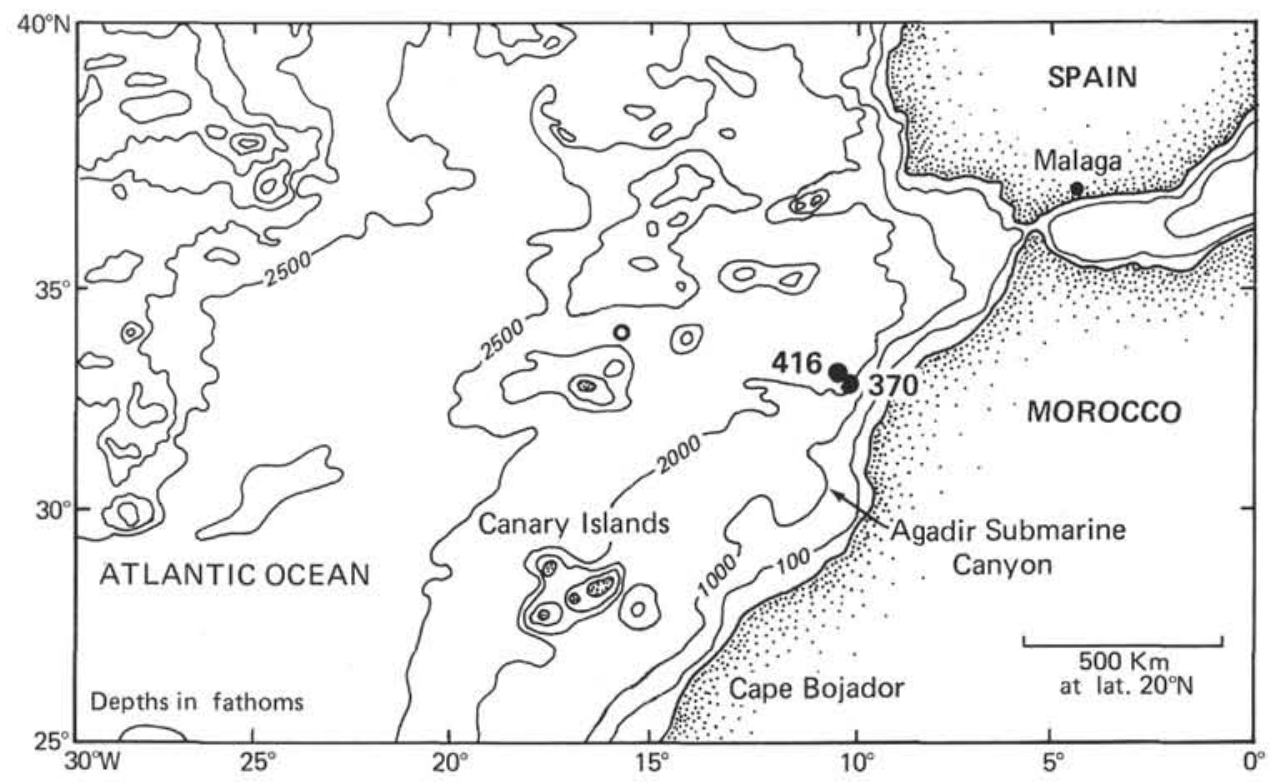

Figure 1. Location of DSDP Sites 416 and 370.

may result in elimination of index species. The possibility that biostratigraphic boundaries, as placed here, are stratigraphically too high thus should be kept in mind. The identification of the Jurassic/Cretaceous boundary in particular is equivocal, as shown by the slight discrepancy between various fossil groups for the levels of first occurrence of Berriasian markers. Calcareous nannofossils show the lowest stratigraphic occurrence of Cretaceous species, and nannofossil data were utilized here for placement of this boundary (see discussion in Vincent et al., this volume).

Epoch boundaries based on palynological data are consistently higher in the section than those based on calcareous nannofossil data, a discrepancy also observed at DSDP Site 367 in the Cape Verde Basin to the south and in wells of the Atlantic continental margin of North America. Considering the uncertainty in correlating the palynological zonation with the standard European stages, palynological data were not taken into account here for age assignment of the Jurassic-Neocomian sequence (see Vincent et al., this volume).

Average accumulation rates were estimated using van Hinte's $(1976 a, b)$ time scale for age assignments of epoch boundaries (Figure 5). However, the poor preservation of faunas and floras and the rarity of biostratigraphic data throughout the sequence does not permit a detailed reconstruction of sedimentation rates. The values given in Figure 5 thus represent only average rates of accumulation for entire intervals, without taking into account either short-term variations within each of these intervals or possible hiatuses. Short-term fluctuations in accumulation rates probably occurred, in view of the episodic nature of turbidite sedimentation. The presence of one or more hiatuses is not excluded. For example, it is not clear from nannofossil data whether a hiatus exists between the Berriasian and the Valanginian (Čepek et al., this volume).
There is no direct paleontological evidence of the exact age of the lowermost sediments reached at Site 416 . However, assuming that Jurassic deposits accumulated at the same rate as those of the overlying Berriasian (10 $\mathrm{m} / \mathrm{m} . \mathrm{y}$.), the sediments at the base of the hole would be of early Tithonian-late Kimmeridgian age, approximately $140 \mathrm{~m}$.y. old.

The entire Valanginian-Hauterivian section accumulated at the high average rate of $65 \mathrm{~m} / \mathrm{m}$.y. No nannofossil zonal boundaries could be identified in this sequence which encompasses the interval from the Cretarhabdus angustiforatus Zone to the Lithraphidites bollii Zone. However, foraminifer datum levels were identified, marking the Valanginian/Hauterivian boundary and possibly the lower/upper Valanginian boundary. Although the latter is not clearly marked, there is some evidence that it occurs near Core 416A-32 (Dorothia prehauteriviana, an upper-Valanginian index fossil, occurs in and above the latter core, and Trocholina valdensis, a lower-Valanginian index fossil occurs below it).

The highest occurrence of the nannofossil $R u$ cinolithus wisei (middle Valanginian) in Core 416A-31 supports this assumption. It thus appears that the upper-Valanginian section accumulated at a higher average rate (about $71 \mathrm{~m} / \mathrm{m} . \mathrm{y}$.) than the underlying lower Valanginian $(56 \mathrm{~m} / \mathrm{m} . \mathrm{y}$.$) and the overlying Hauterivian$ $(67 \mathrm{~m} / \mathrm{m} . \mathrm{y}$.). This inference is in agreement with an increased influx of redeposited shallow-water material during that time (Sliter, this volume; see right side of Figure 5). It is also that interval to which the maximum occurrence of calcisphaerulids, which are part of the calcareous redeposited material, corresponds (Bolli, this volume; Sliter, this volume).

The disappearance of micritic limestone beds (marking the top of lithologic unit VII) near the end of the Early Valanginian is correlated by Schlager (this vol- 
SITES 416 and 370 (Lat. 3250.2 'N; Long. 1048.1 W)

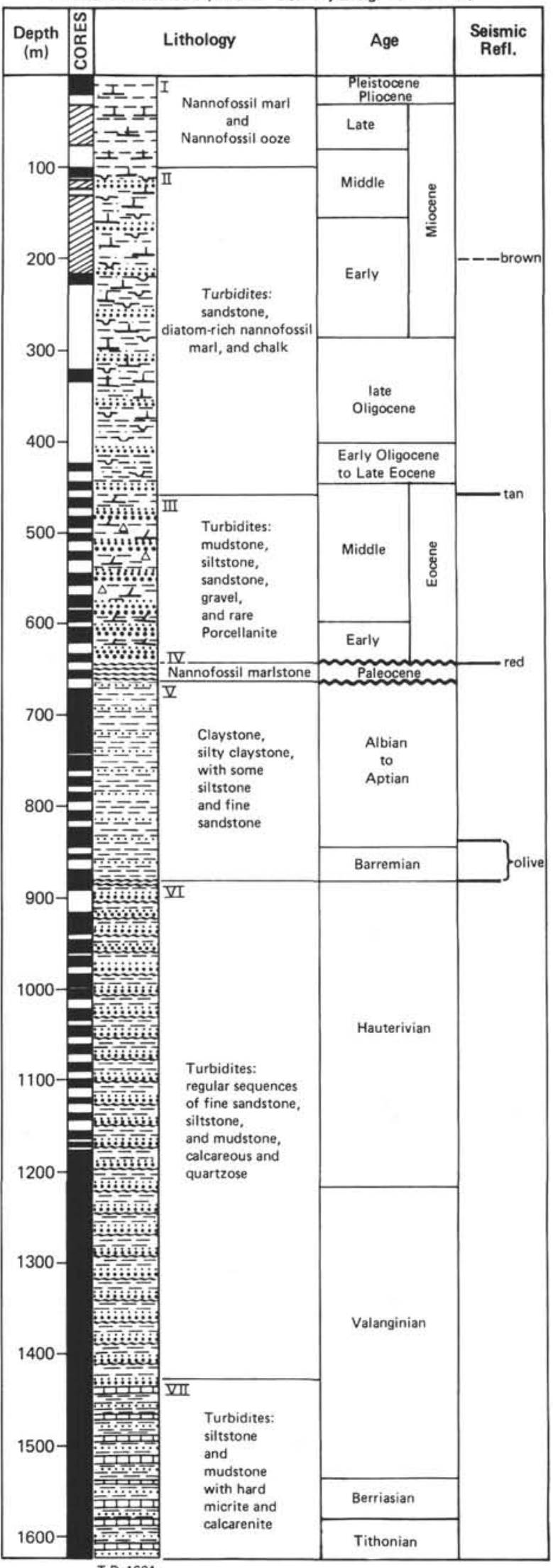

Figure 2. Stratigraphic summary at DSDP Sites 416370.

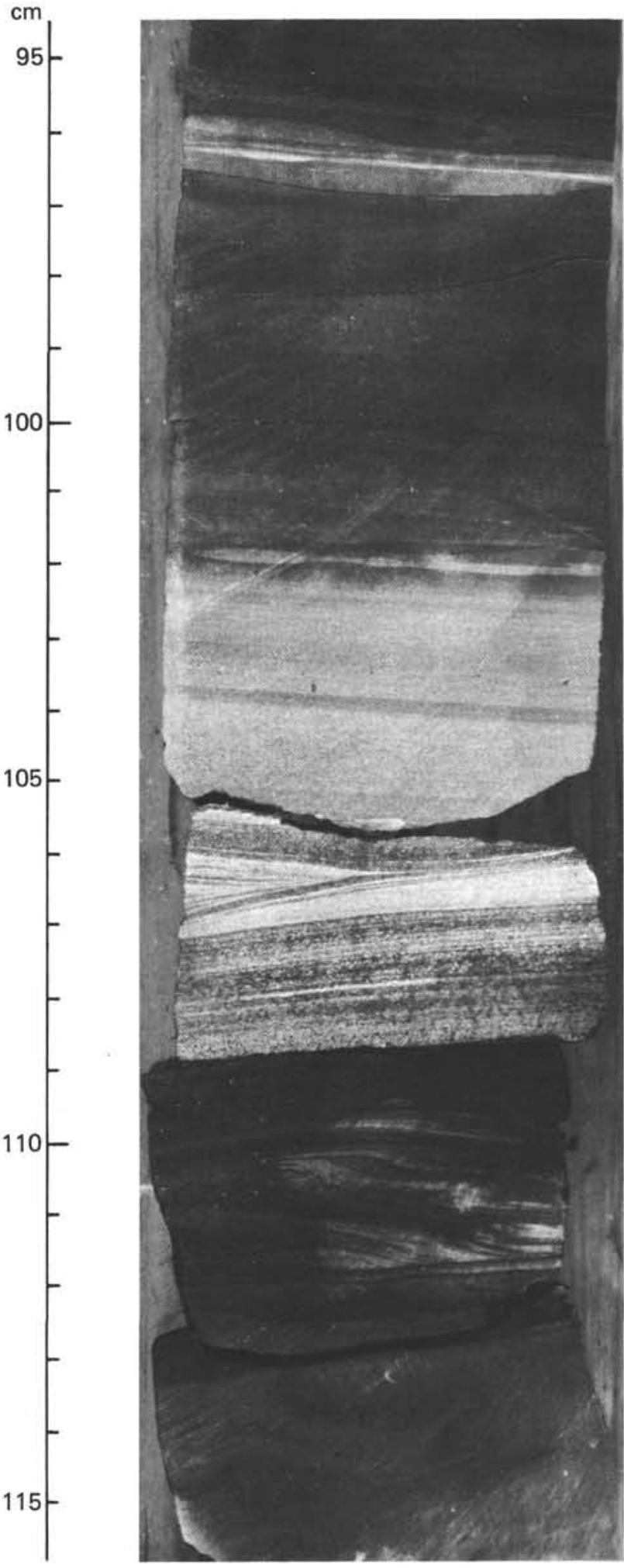

Figure 3. Core 416A-37-2, 95-115 cm. Calcareous turbidite cycle from 109 to $97 \mathrm{~cm}$ begins with cross-stratified calcarenite of Bouma division $C$, with abundant micrite grains, redeposited calpionellid-limestone grains, calcispheres, thin-shelled mollusks, and quartz. The sediments are slightly more marly upward, but most of the change is simply a decrease in grain size. A few secondary dolomite rhombs occur in the upper part of the bed. 


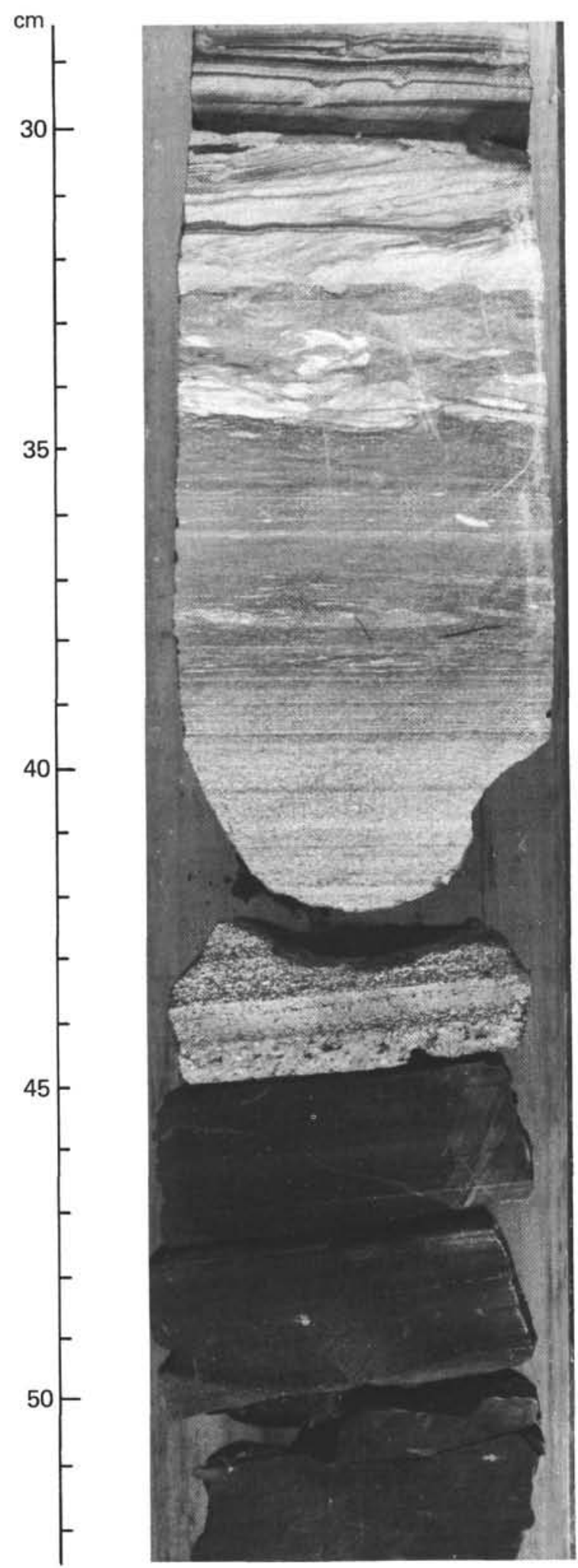

Figure 4. Core 416A-37-2, 30-50 cm. Calcareous turbidite layer, beginning at $44 \mathrm{~cm}$. The base is coarse calcarenite with micritized benthic foraminifers; mollusk, echinoid, and bryozoan fragments; ooids; lumps of calpionellid limestone (dark); glauconite; and phosphatic fish debris. ume) with the drowning of offshore carbonate banks at that time. During the remainder of the Valanginian, there was a general decline in calcareous clastic influx, as evidenced by an upward decrease in the ratio of carbonate to terrigenous detritus in lithologic unit VI. Calcareous detritus disappears above Core 416A-25.

\section{OCCURRENCE OF CALPIONELLIDS}

Calpionellids occur sporadically throughout the Tithonian-Valanginian interval, between approximately 1575 and 1330 meters (Cores 416A-52 through 25). Only a few isolated, reworked calpionellids were found above 1330 meters in the Hauterivian (Cores 416A-7 through 9), in sediments where coarse calcareous clastics are absent.

Calpionellids are associated with the calciturbidites. They are rare in some layers, common in others. The facies with which they are associated do not compare with the classic calpionellid limestones of the Mesozoic Tethyan realm. These are pelagic and typically consist of homogenous micrite with scattered, evenly distributed calpionellids, and they are rich in other pelagic components, such as nannofossils and radiolarians (see for example pl.35 in Colom, 1948). At Site 416, calpionellids and all other calcareous materials are redeposited, as shown by microfacies analysis. Calpionellids occur either isolated within mudstone and siltstone, or embedded in clasts of micritic limestones. In the first case, they are usually unevenly distributed, and concentrated either in patcheds or in thin layers. They are generally well sorted (see Plate 1). In the second case, the clasts are found in calcarenite layers near the base of calciturbidite sequences, together with other clasts such as ooids; peloids; fragments of aptychi, bivalves, and echinoids; and benthic foraminifers (see Plates 2 and 3). Many of these clasts appear to have undergone severe deformation, probably because they were still soft at the time they were redeposited (Schlager, this volume).

Calpionellids were studied from thin sections and acetate peels in lithified rocks (these rocks, however, often were not indurated enough and had to be impregnated before thin sections could be cut). Calpionellids and their associated microfacies observed in thin sections and acetate peels are illustrated in Plates 1 to 5 . Calpionellids were also recovered from soft sediments, and isolated specimens were then studied from coarsefraction residues. In the latter case, two techniques were used: (1) isolated specimens from residues coarser than $63 \mu \mathrm{m}$ were examined with a scanning electron microscope (Plates 6-8; see also Bolli, this volume, who illustrates a few isolated calpionellids obtained from residues $>44 \mu \mathrm{m}$ ); and (2) strewn slides were examined under a light microscope (Plate 9). The preparation of strewn slides follows the standard technique used for radiolarian preparation, except that no acid was used. Residues coarser than $44 \mu \mathrm{m}$ were suspended in water, then pipetted on to a slide, dried, and mounted in Caedax. 


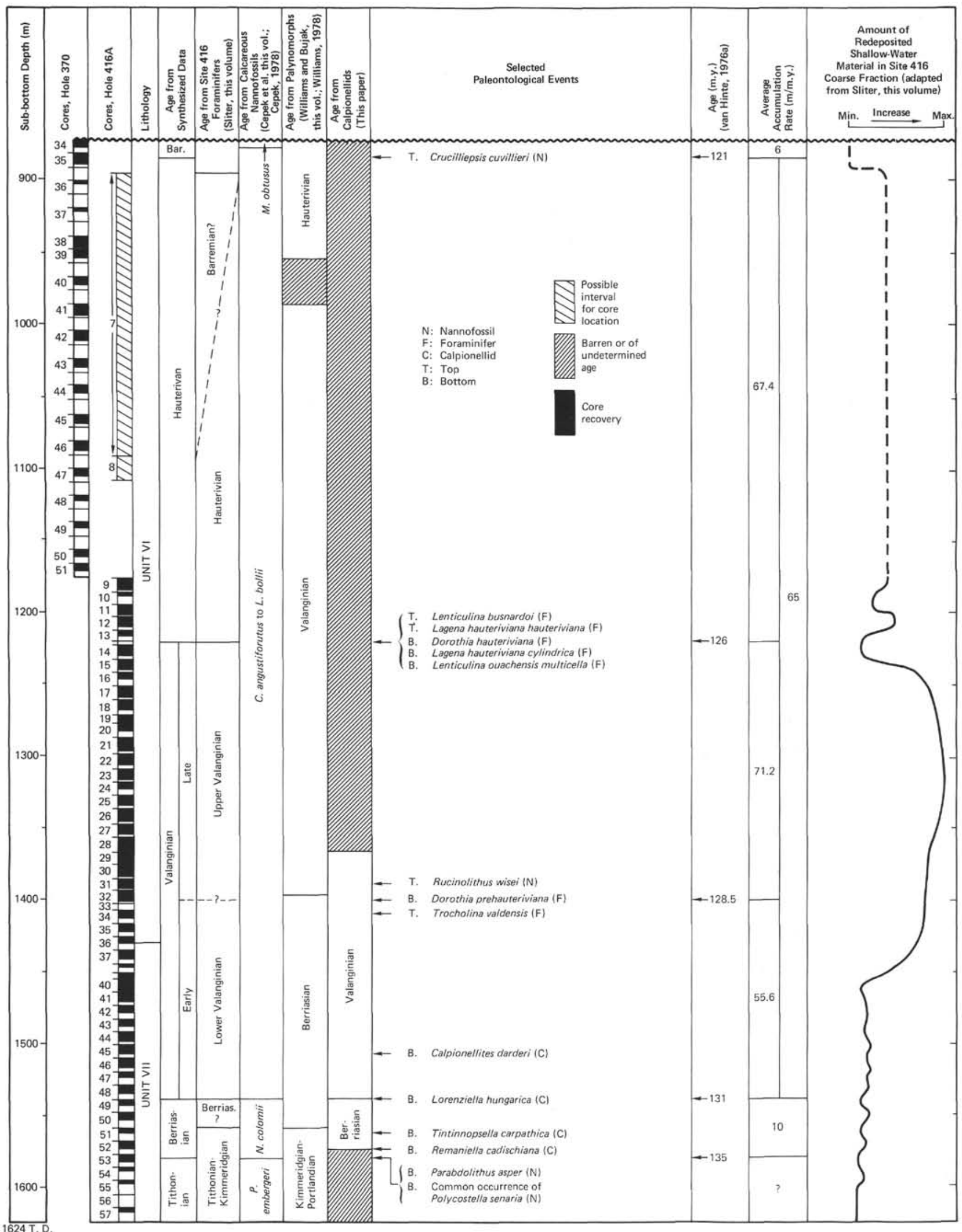

Figure 5. Jurassic-Neocomian sequence at Sites 416-370. Biostratigraphy, average sediment accumulation rates, and quantitative estimate of redeposited shallow-water material in coarse fractions. 
Calpionellids are almost exclusively described and illustrated from thin sections, where loricae are encountered in random sections of unknown orientation. In most pelagic limestones sufficient material is available to recognize diagnostic taxonomic characters (shape and size of the lorica, form and position of the collar, development of a caudal appendage) in longitudinal axial views. Studies of isolated specimens illustrated with scanning electron micrographs remain very rare (Luterbacher, 1972; Aubry et al., 1976), and the microstructure of the wall is still poorly known. ${ }^{4}$

From their study, Aubry et al. (1976) suggested that the primary wall structure of calpionellids consists of spirally arranged calcite prisms normal to the surface of the lorica and that diagenetic transformations of the crystallites depend upon the lithologic nature of the fossilizing environment. Many more SEM studies are needed to determine whether replacement of the original crystallites in a specimen has taken place or not, and how replacement arrangements compare with the original crystallites. Bolli $(1974,1978)$ has shown that crystallite arrangements in the wall of some calcisphaerulids remain very similar over wide geographic areas. SEM illustrations in the present study are thus valuable for comparison with specimens from other areas.

We believe that the combination of the three different methods of observation (thin section, strewn slides, and SEM) of specimens of calpionellids from a single stratigraphic horizon is especially interesting in that it allows for comparison among various aspects of whole and sectioned loricae. Strewn slides of unconsolidated sediments were found particularly useful because they are very easy to prepare and permit an almost immediate three-dimensional investigation of morphological features by use of slight changes in optical focus.

\section{DISTRIBUTION OF CALPIONELLID SPECIES}

Species which were identified are illustrated on Plates 4 to 9 and their occurrence is shown in Table 1. Many specimens were undifferentiated. Calpionellids are known to be restricted to uppermost-Jurassic and Lower Cretaceous sediments. With the exception of one genus (Colomiella), they all belong to the Family Calpionellidae that ranges from middle Tithonian to middle Valanginian (Remane, 1978). From available zonal schemes

\footnotetext{
${ }^{4}$ Scanning electron micrographs of tintinnomorph shells of Eocene-Oligocene strata illustrated by Tappan and Loeblich (1968) are not representative of calpionellids, because the two fossil groups are not related. The Eocene-Oligocene forms have been placed in a taxon incertae sedis (the Pseudarcellida) by Aubry et al. (1976). Pelagic Mesozoic calpionellids, thought by many workers to be fossil tintinnids, are not related to the latter group, from which they differ by having a calcareous test, whereas Recent tintinnids possess an organic test, sometimes bearing surficially agglutinated materials (Remane, 1978). Remane (1978) emphasizes that mineralized tests are unknown not only in Recent tintinnids, but also in ciliates as a whole, and he groups calpionellids in one superfamily (Calpionellidea) placed among Protozoa incertae sedis. The three groups mentioned above have an overall morphological resemblance in that they possess a bellshaped test (the lorica).
}

TABLE 1

Distribution of Identified Calpionellid Species at Site 416

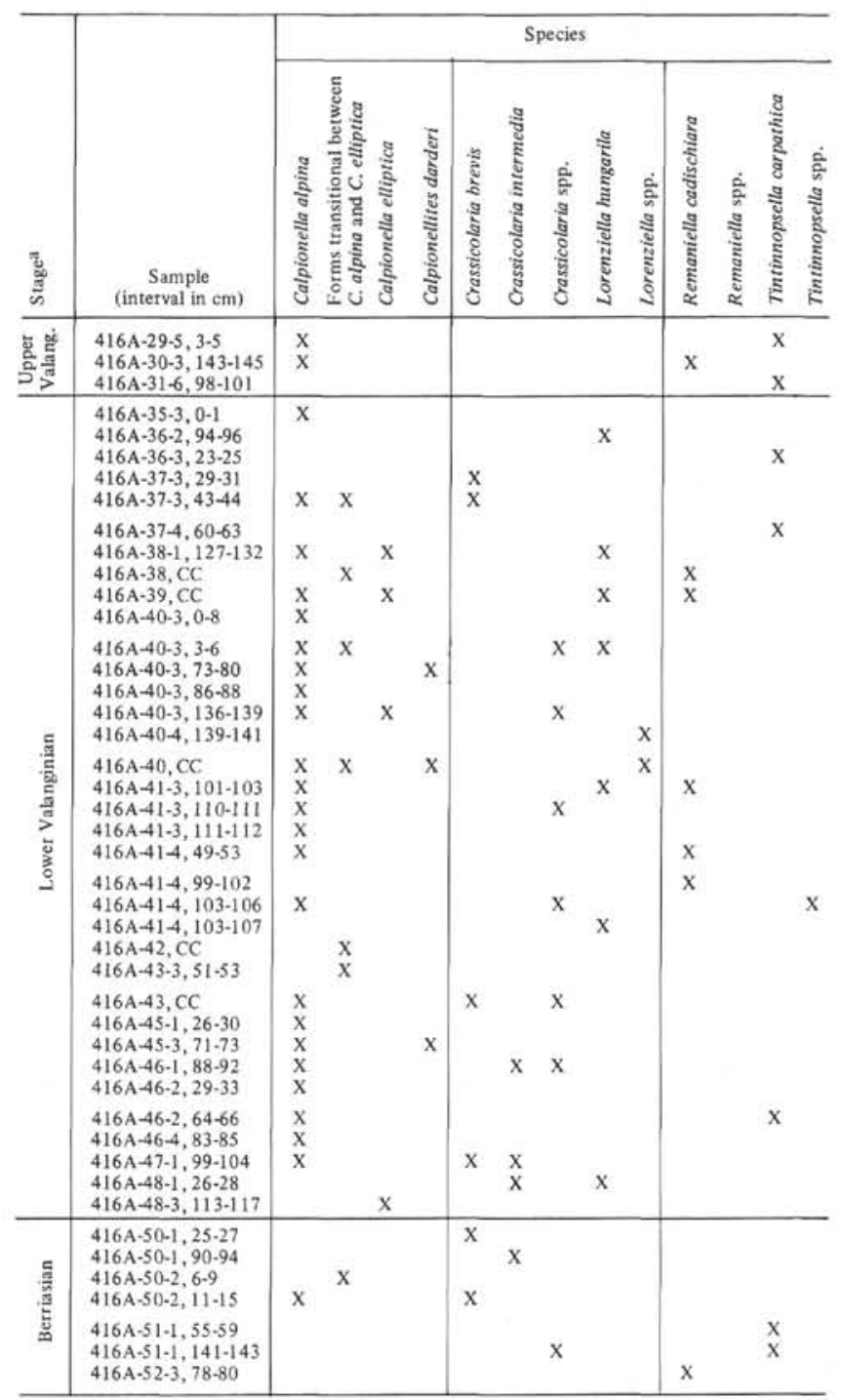

astages are from Figure 5 .

(Allemann et al., 1971; Remane, 1971, 1978), only first occurrences of species (plotted on Figure 5) could be used here for biostratigraphy, because calpionellids, like all other fossil groups in the Jurassic-Neocomian sequence at Site 416, exhibit common upward reworking.

No calpionellids were found in the lowermost part of the section below Core 416A-52, which is assigned a Jurassic age on the basis of other fossil groups. Limestones from Core 416A-57, however, exhibit microfacies with micritic pellets very similar to those of limestones higher in the section which contain calpionellids (compare Plate 3, Figures 5, 6 with Figure 7). The absence of calpionellids in the lowermost limestones thus may support their early Tithonian age (prior to calpionellid appearance) inferred from sedimentation-rate data.

Remaniella cadischiana, known to appear first at the base of the Berriasian, occurs in Core 416A-52, slightly above the Tithonian/Berriasian boundary based on nannofossil data. Slightly above this level, Tintinnopsel- 
la carpathica, a typically Cretaceous form (excluding the small variety of earliest calpionellids), first occurs in Core 416A-51. The first occurrence of Lorenziella hungarica, known to have evolved near the Berriasian/ Valanginian boundary, first occurs in Core 416A-48, at a level in accord with the placement of this boundary on the basis of foraminifer and nannofossil data. Calpionellites darderi, a lower-Valanginian index fossil, occurs in a few lower-Valanginian beds. Rare specimens of Tintinopsella carpathica and ?Remaniella morgeanu, species that became extinct in the middle Valanginian, are reported by Bolli (this volume) in an Hauterivian horizon (within Core 416A-9), near levels in which we found undifferentiated calpionellids (within Cores 416A-7 and 8).

The most common forms encountered throughout the sequence are Calpionella alpina, (mostly the smaller, spherical variety typical of strata near the Jurassic/Cretaceous boundary). A few transitional forms between $C$. alpina and C. elliptica were observed, and very few specimens referable to $C$. elliptica (a lower-Berriasian species) were recognized in lower-Valanginian sediments.

\section{CONCLUSIONS}

Calpionellids commonly occur in Berriasian to lowermost upper Valanginian distal turbidites at Site 416, in the deep Moroccan Basin. The micritic lumps and pellets in which they are found indicate that pelagic calpionellid lime muds occurred higher up on the eastern slope of this basin.

Like all other calcareous material at Site 416, calpionellids are redeposited in distal turbidites. Redeposition, however, appears to have been mostly penecontemporaneous, as indicated by the normal order of first occurrences of species. The severe deformation of redeposited calpionellid-rich clasts, suggesting that these were still soft at the time they reached the basin, also adds support to this interpretation. Calpionellid biostratigraphy here is thus possible and appears consistent with biostratigraphic schemes based on other calcareous fossils.

Continued redeposition, however, is evidenced by the “'artificial"' extension of upper ranges of species. Influx of calcareous detritus ceased at Site 416 some time in the late Valanginian, but subsequent sporadic erosion of the older slope took place during the Hauterivian, as evidenced by the occurrence of a few calpionellids in some strata of that age at Site 416.

\section{ACKNOWLEDGMENTS}

We are indebted to the management of ESSO EPR-E, Bègles, France, for permission to allow R. Lehmann to participate in this study. We thank Hans R. Thierstein (Scripps Institution of Oceanography) for discussion of nannoplankton biostratigraphy, and Isabella Premoli-Silva (Universita di Milano) who critically reviewed the manuscript. We also thank our shipboard colleagues who helped complete our collection of peels and thin sections on board the ship, as well as in various laboratories, both in France and in the U. S. This study was supported under NSF Grant OCE76-83359 to Vincent.

\section{REFERENCES}

Allemann, F., Catalano, R., Farès, F. and Remane, J., 1971. Standard calpionellid zonation (upper Tithonian-Valanginian) of the western Mediterranean Province. In Proceedings of the Second International Planktonic Conference (Roma 1970), v. 2, pp. 1337-1340.

Aubry, M. P., Bignot, G., Bismuth, H., and Remane, 1976. Premiers résultats de l'observation au M. E. B. de la lorica des Calpionelles et de quelques microfossiles qui leurs sont associés. Revue de Micropaléont., v. 18, pp. 127-133.

Bolli, H. M., 1974. Jurassic and Cretaceous Calcisphaerulidae from DSDP Leg 27, eastern Indian Ocean. In Veevers, J., Heirtzler, J. R., et al. Initial Reports of the Deep Sea Drilling Project., v. 27: Washington (U. S. Government Printing Office), pp. 843-907.

1978. Cretaceous and Paleogene Calcisphaerulidae from DSDP Leg 40, southeastern Atlantic. In Bolli, H. M., Ryan, W. B. F., et al. Initial Reports of the Deep Sea Drilling Project, v. 40: Washington (U. S. Government Printing Office), pp. 819-838.

Brun, L., 1962. Quelques Tintinnoidiens du Berriasien associés à une microfaune du Sud Ouest Maroccain. Notes Serv. Géol. Maroc., 156, pp. 101-103.

Cepek, P., 1978. Mesozoic calcareous nannoplankton of the eastern North Atlantic, Leg 41. In Lancelot, Y., Seibold, E., et al. Initial Report of the Deep Sea Drilling Project, v. 41: Washington (U. S. Government Printing Office), p. 667-687.

Colom, G., 1948. Fossil tintinnids: loricated Infusoria of the order of the Oligotricha. J. Paleont., v. 22, pp. 233-263.

Choubert, G. and Faure-Muret, A., 1962. Evolution du domaine atlasique marocain depuis les temps paléozoiques. In Livre à la Mémoire du Professeur P. Fallot, Mém. hors. série Soc. Géol. France, t. 1, pp. 447-527.

Hottinger, L., 1966 Résumé de la stratigraphie micropaléontologique du Mésozoique et du Tertiaire Marocain. In Proceedings of the Second West African Micropaleontological Colloquium (Ibadan, 1965), pp. 92-104.

Lancelot, Y., Seibold, E., et al., 1978. Initial Reports of the Deep Sea Drilling Project, v. 41: Washington (U. S. Government Printing Office).

Luterbacher, H., 1972. Foraminifera from the Lower Cretaceous and Upper Jurassic of the northwestern Atlantic. In Hollister, C. D., Ewing, J. I., et al., Initial Reports of the Deep Sea Drilling Project, v. 11: Washington (U. S. Government Printing Office), pp. 561-593.

Remane, J., 1971. Les Calpionelles, Protozoaires planctoniques des mers mesogéennes de l'époque secondaire. Ann. Guebhard, v. 47, pp. 4-25.

, 1978. Calpionellids. In Haq, B. U., and Boersma, A., (Eds.), Introduction to Marine Micropaleontology: New York (Elsevier), pp. 161-170.

Sociéte Chérifienne des Pétroles, 1966. Le bassin du sud-ouest marocain. In Reyre, D., (Ed.). Sedimentary Basins of the African Coasts: Paris (Assoc. African Geol. Surveys), pp. 5-12.

Tappan, H., and Loeblich, A. R., Jr., 1968. Lorica composition of modern and fossil Tintinnida (ciliate Protozoa), systematics, geologic distribution, and some new Tertiary taxa. J. Paleont., v. 42, pp. 1378-1394.

van Hinte, J. E., 1976a. Jurassic time-scale. Bull. Am. Assoc. Petrol. Geol., v. 60, pp. 467-497.

1976b. A Cretaceous time scale. Bull. Am. Assoc.

Petrol. Geol., v. 60, pp. 498-516. 
Viotti, C., 1965. Microfaunes et microfaciès du sondage Puerto Cansado 1 (Maroc Méridional-Province de Tarfaya). Bur. Rech. Géol. Min. Mém., v. 32, pp. 29-60.

Williams, G. L., 1978. Palynological biostratigraphy, Deep Sea Drilling Project Sites 367 and 370. In Lancelot, Y., and
Seibold, E., et al., Initial Reports of the Deep Sea Drilling Project, Supplement to Volumes 38, 39, 40, and 41: Washington (U. S. Government Printing Office), pp. 783-813. 



\section{PLATE 1}

Microfacies of lithified beds in lithologic unit VII at DSDP Site 416. All figures are micrographs of thin sections.

Laminated, micritic calcisiltite to quartz siltstone, rich in calpionellids. Quartz grains are scattered or in layers. Calpionellids are either randomly distributed (Figures 1 and 3) or concentrated in layers (Figures 2, 4, and 5). In the latter case, they are hydrodynamically sorted. Note how light weight calpionellids occur just above layers of slightly smaller quartz grains (Figures 4 and 5).

Figures 1, 2 Sample 416A-40-3, 73-80 cm $(\times 65)$. Note in Figure 1 Calpionellites darderi (dar) showing inward-directed terminal bifurcation.

Figure 3 Sample 416A-40-3, 136-139 cm $(\times 65)$.

Figures 4, 5 Sample 416A-41-1, 29-34 cm $(4, \times 65 ; 5, \times 85)$. 
PLATE 1
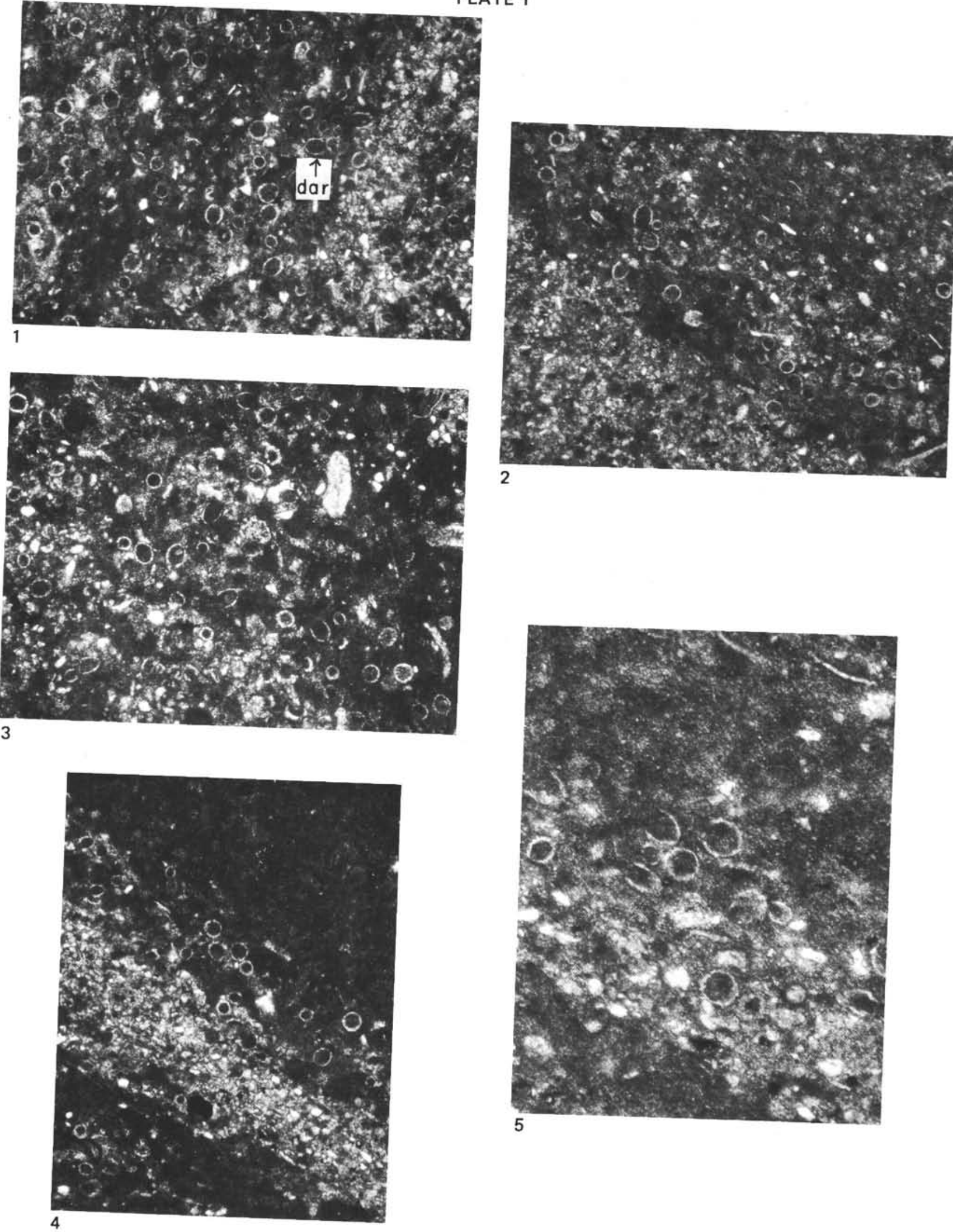
PLATE 2

Microfacies of lithified beds in lithologic unit VII. Micrographs of acetate peels (Figures 1-4) and of thin sections (Figures 5-7).

Figures 1-6 Micritic limestone with various skeletal debris. Patches of microsparite. Rare calpionellids.

1, 2. Sample 416A-36-2, $92-96 \mathrm{~cm}(\times 150)$. Unidentified skeletal debris.

3 , 4. Sample 416A-40-3, 0-8 cm ( $\times 150)$. Fragments of pelecypods.

5, 6. Sample 416A-41-3, 110-111 cm (× 65).

5. Benthic foraminifers: spirillinid (spi), Vidalina (vid; the dark arenceous wall is scarcely distinguishable from the micritic matrix, and only the chamber voids filled with calcite are clearly visible).

6. Aptychus and echinoid fragments.

Figure $7 \quad$ Argillaceous mudstone with scattered quartz grains, calpionellids, and microfillaments (pelecypod fragments). Sample 416A-47-1, 99-104 cm (× 65). 
PLATE 2

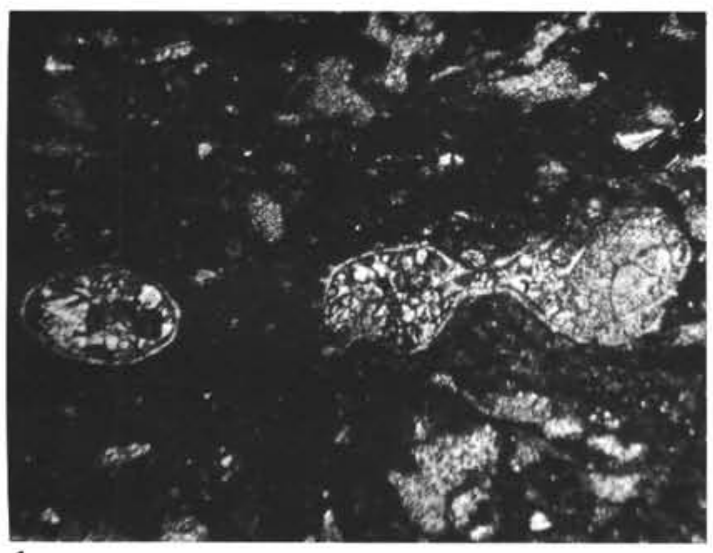

1

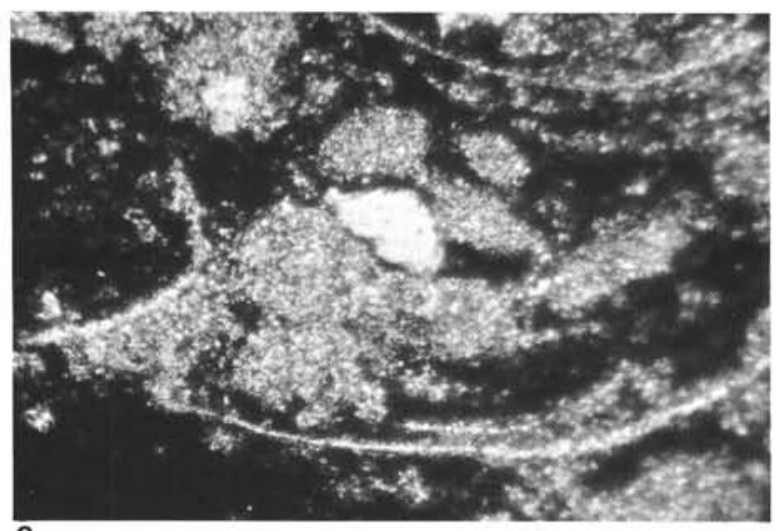

3

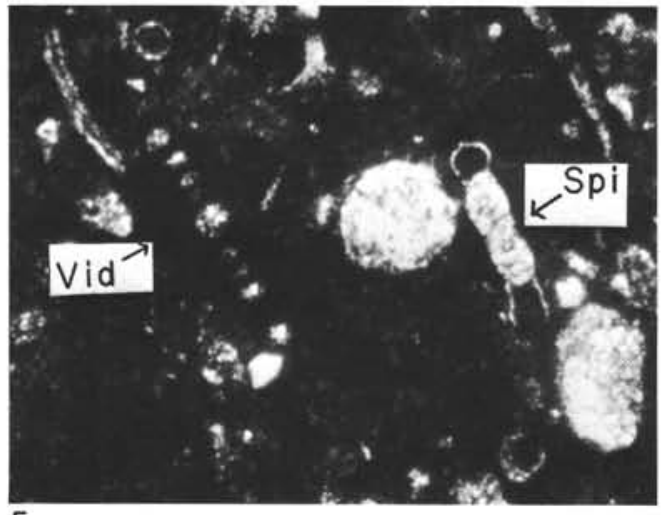

5

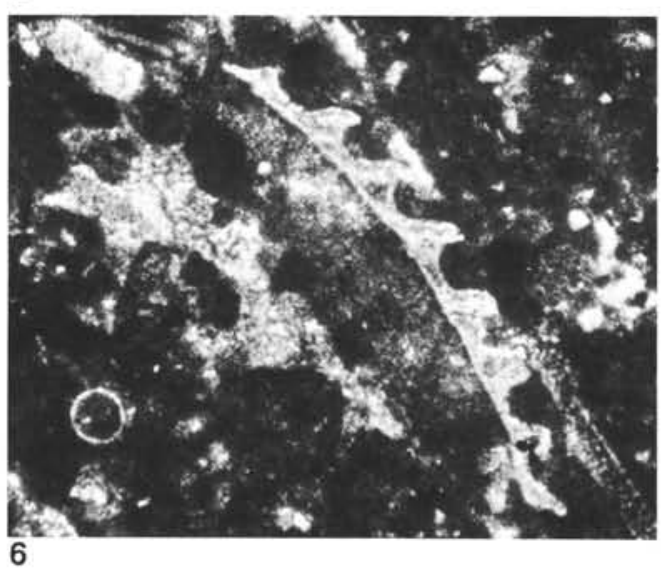

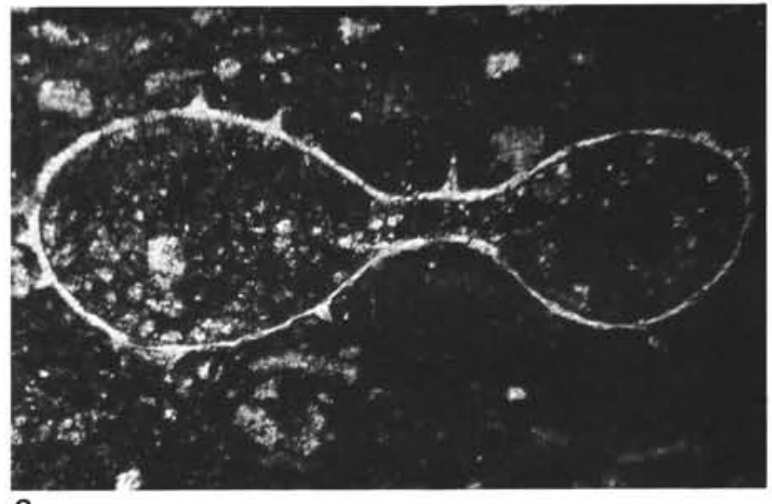

2

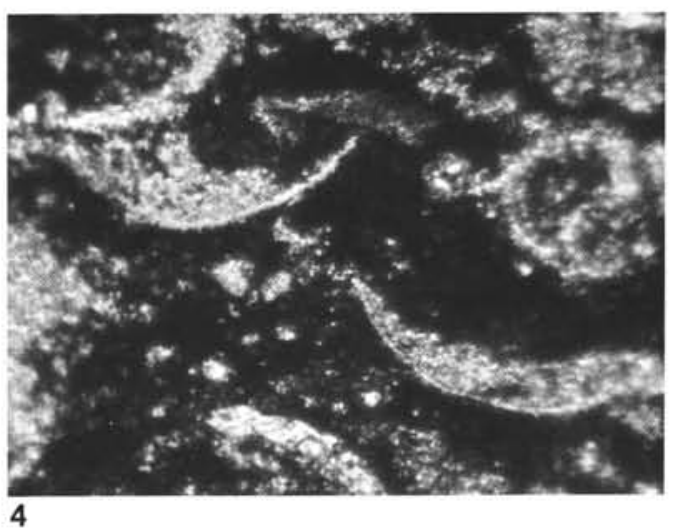

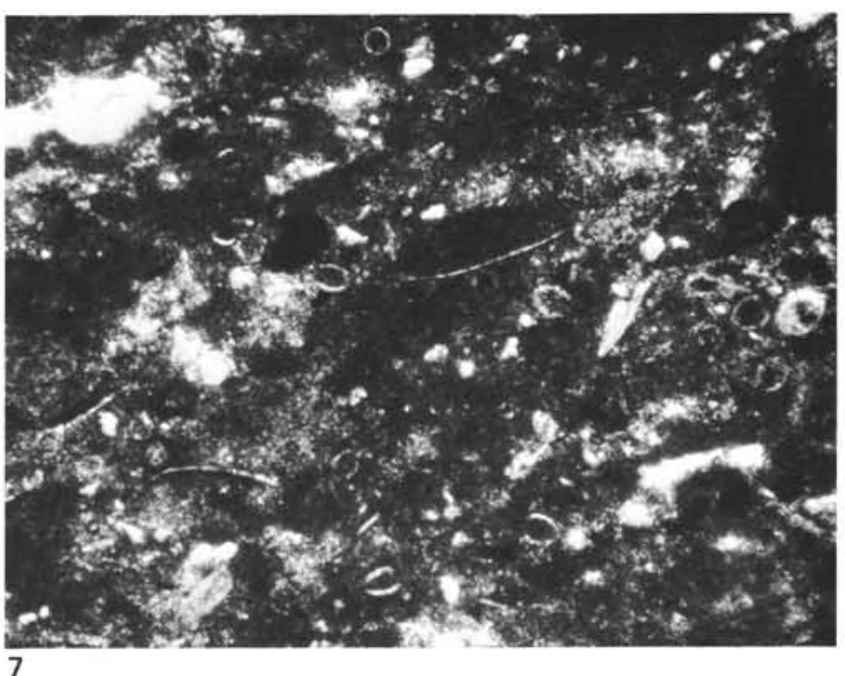


PLATE 3

Microfacies of limestone in lithologic unit VII. All figures are micrographs of thin sections $(\times 65)$.

Figures 1-4 Calcarenite with clasts of micritic, calpionellidbearing limestone, quartz grains, various skeletal fragments, and large shallow-water benthic foraminifers (lower part of calciturbidite).

1-3. Sample 416A-37-3, 29-31 cm .

1. Lenticulina.

2. Trocholina.

3. Aptychus.

4. Sample 416A-51-1, 46-48 cm; rotaliid.

Figures 5-6 Limestone with small well-sorted pellets of argillaceous micrite and small benthic foraminifers. Sparry cement. Rare calpionellids (upper part of calciturbidite).

5. Sample 416A-40-2, 17-22 cm; ophtalmidiids.

6. Sample 416A-51-1, 31-33 cm; textulariid.

Figure 7 Sample 416A-57-1, 148-150. Microfacies similar to that illustrated on Figures 5 and 6, but without calpionellids. Microfilaments (pelecypod fragments). 
PLATE 3

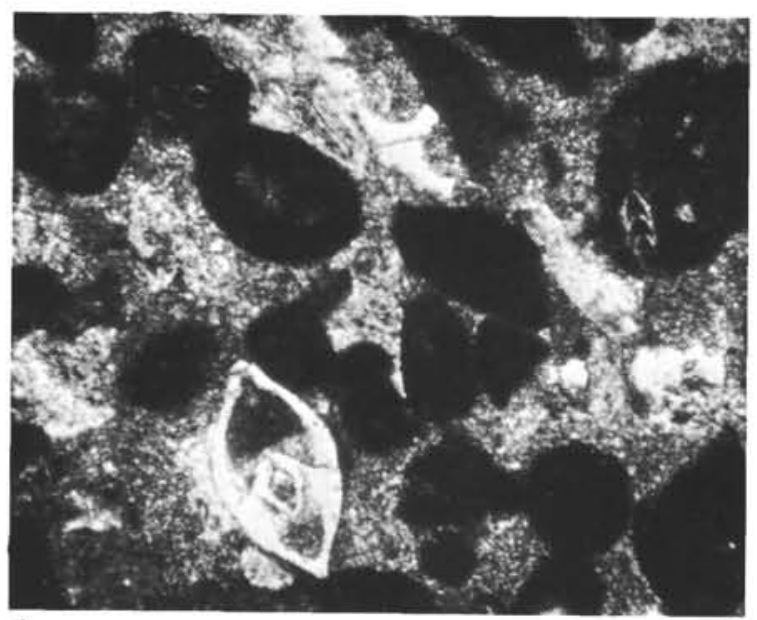

1
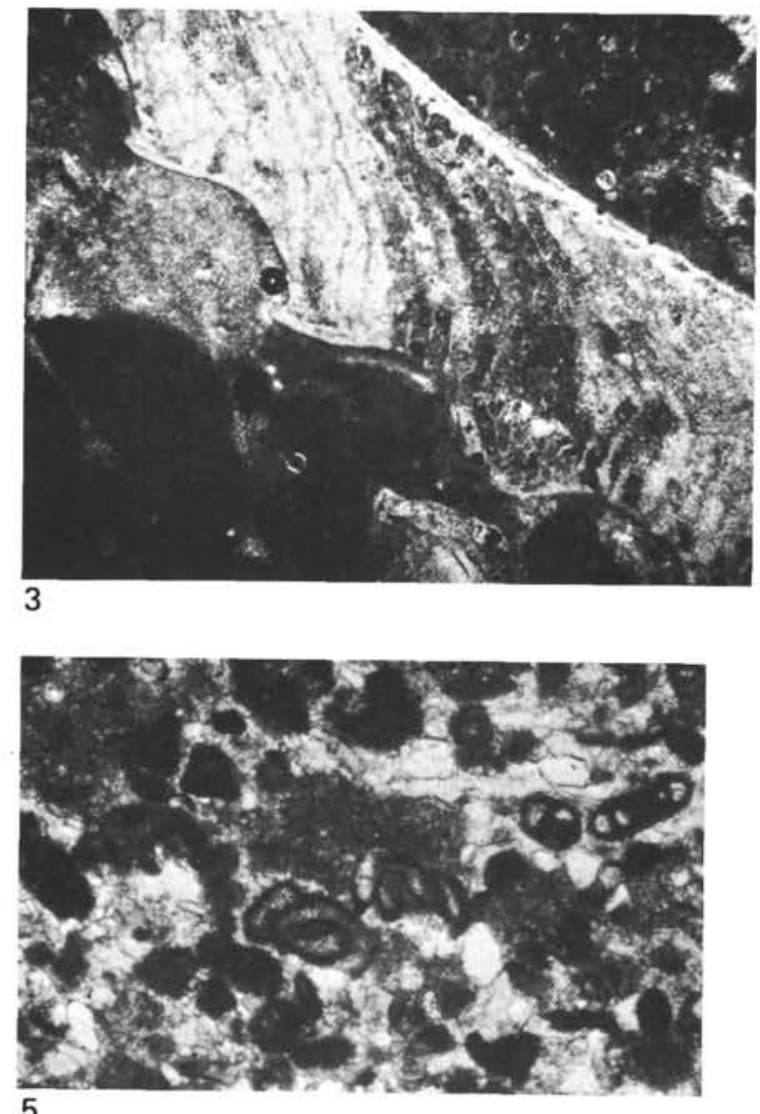
5

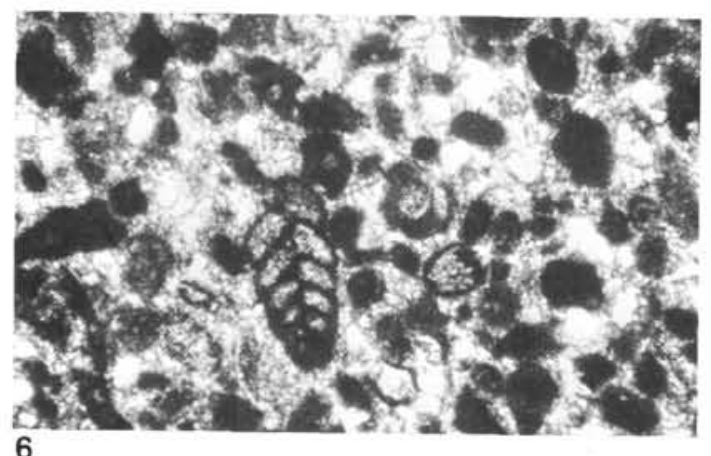

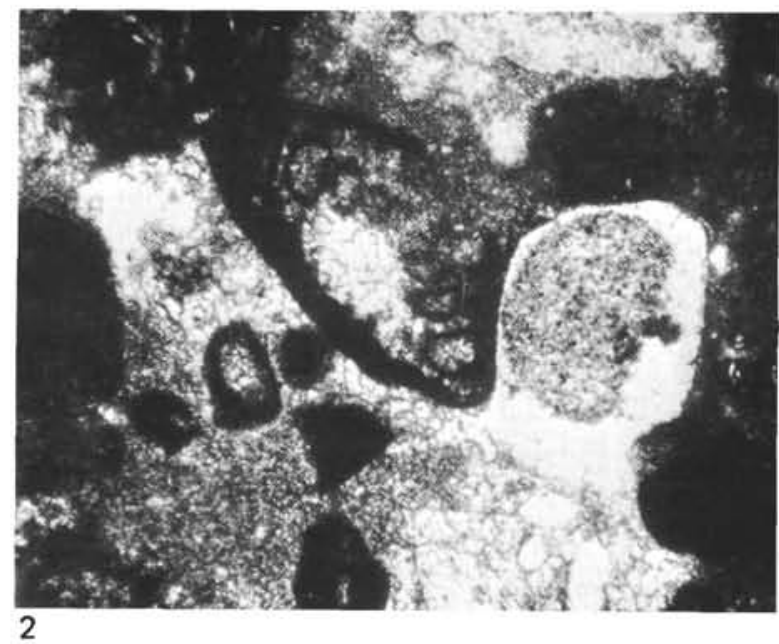
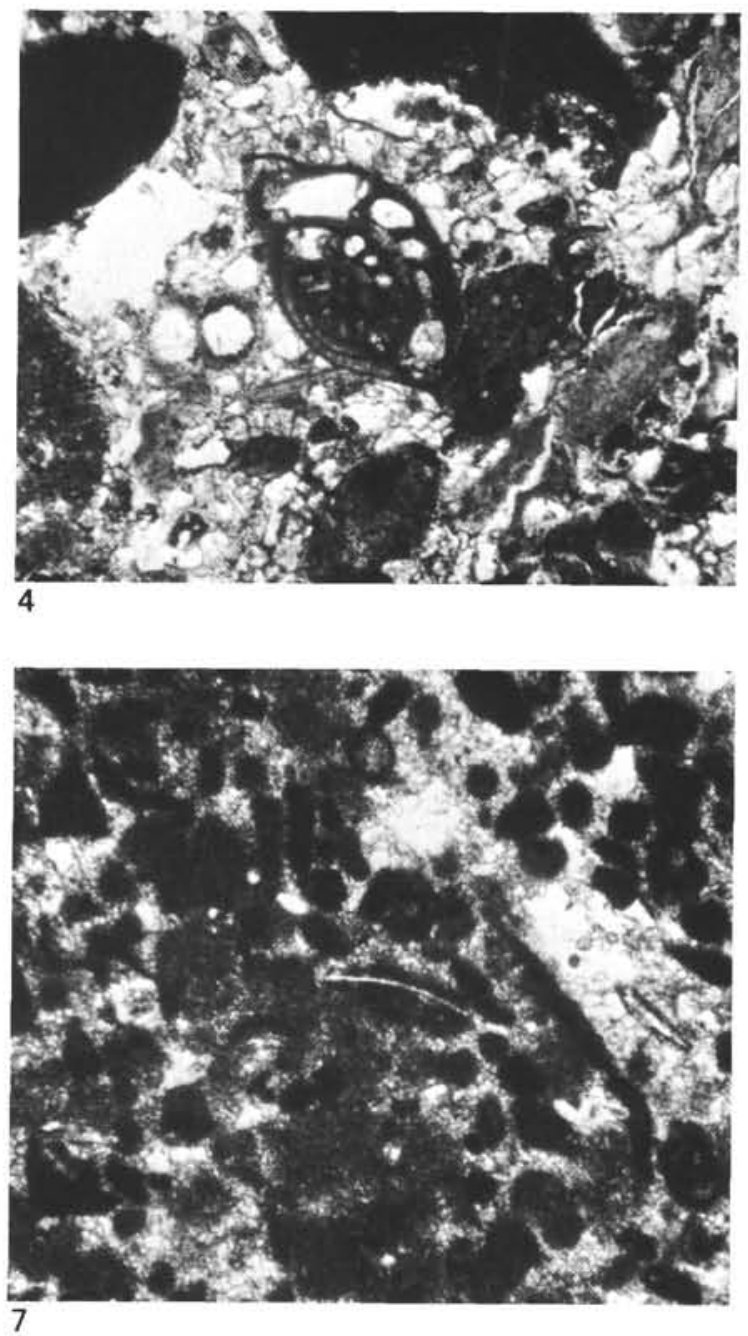
PLATE 4

Calpionellids in thin sections (all figures except Figure 18; $\times$ 250) and acetate peel (Figure $18 ; \times 210)$.

Figures 1-14 Calpionella alpina Lorenz.

1, 2. Sample 416A-37-3, 43-44 cm.

3. Sample 416A-38-1, 127-132 cm.

4. Sample 416A-40-3, 0-8 cm.

5. Sample 416A-40-3, 3-6 cm.

6. Sample 416A-40-3, 73-77 cm.

7. Sample 416A-41-3, 111-112 cm.

8. Sample 416A-41-4, 49-53 cm.

9. Sample 416A-43, CC.

10, 11. Sample 416A-45-1, 26-30 cm.

12. Sample $416 \mathrm{~A}-46-1,88-92 \mathrm{~cm}$.

13. Sample 416A-47-1, 99-104 cm.

14. Sample 416A-50-2, 11-15 cm.

Figures 15, 16 Forms transitional between $C$. alpina and $C$. elliptica.

15. Sample 416A-37-3, 43-44 cm.

16. Sample $416 \mathrm{~A}-43-3,51-53 \mathrm{~cm}$.

Figures 17, 18 Calpionella elliptica Cadisch.

17. Sample $416 \mathrm{~A}-38-1,127-132 \mathrm{~cm}$.

18. Sample 416A-48-3, 113-117 cm.

Figures 19, 20 Remaniella cadischiana (Colom).

19. Sample 416A-41-4, 49-53 cm.

20. Sample $416 \mathrm{~A}-41-4,99-102 \mathrm{~cm}$.

Figures 21-25 Crassicolaria brevis Remane.

21. Sample 416A-37-3, 29-31 cm.

22, 23. Sample 416A-37-3, 43-44 cm.

24, 25. Sample 416A-47-1, 99-104 cm. 


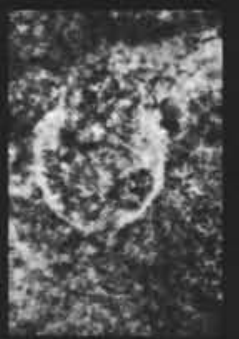

1

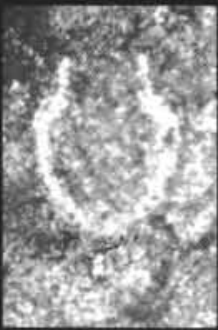

6

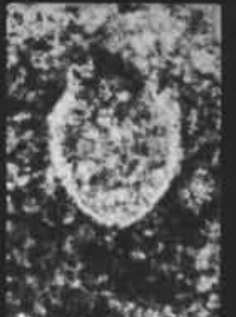
4. Mrogers? 1.1

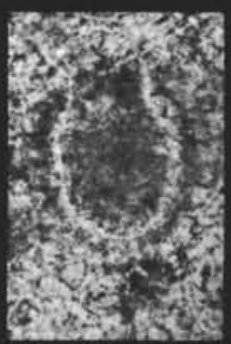

16

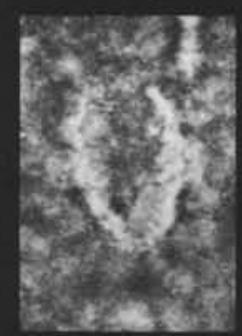

21

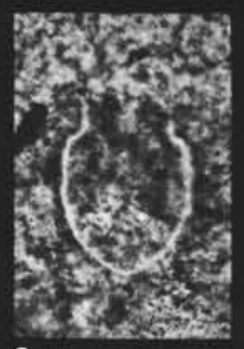

2

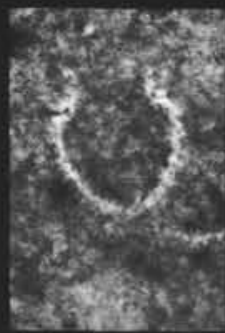

7

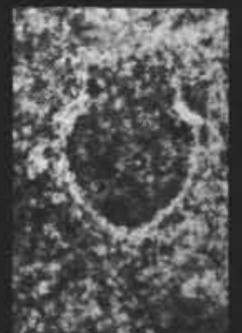

12

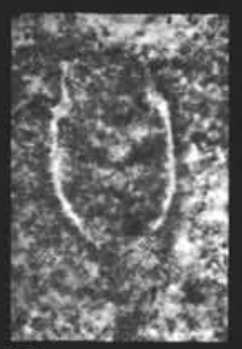

17.

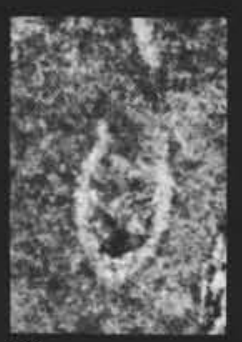

22
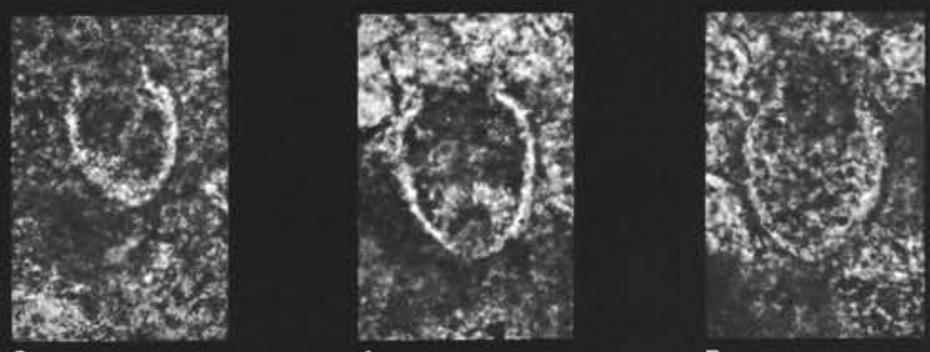

3

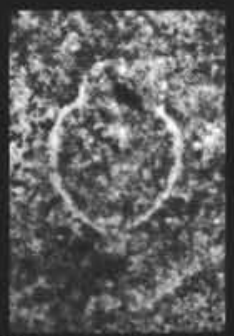

8

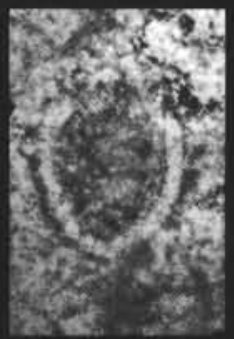

13
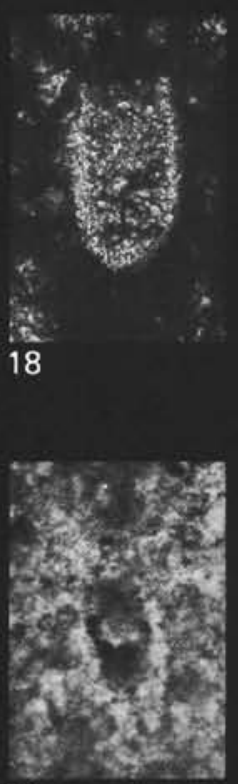

23

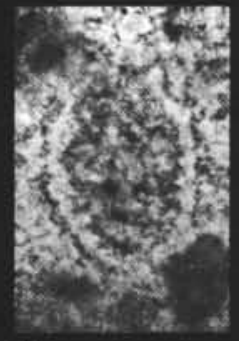

14

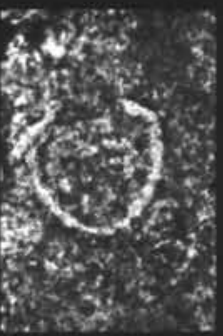

9

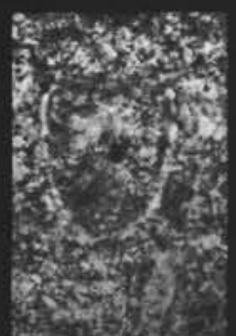

19

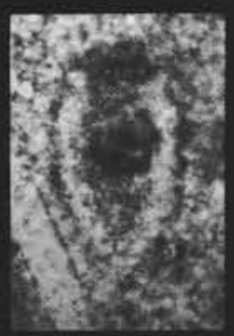

24
5
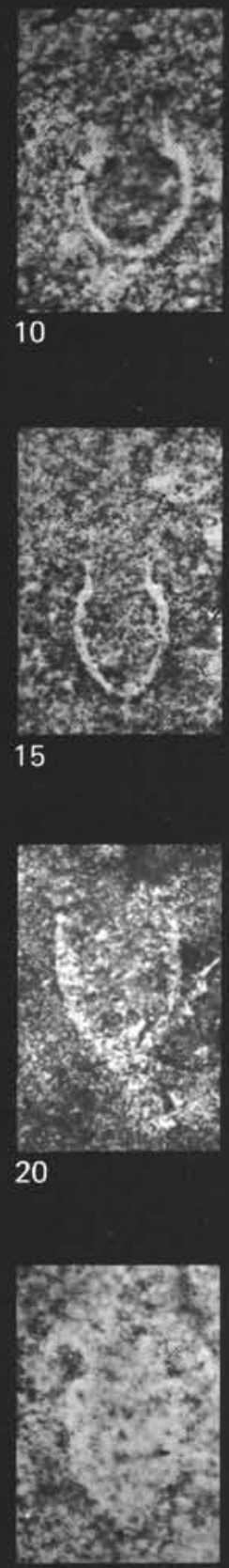

25 


\section{PLATE 5}

Calpionellids in thin sections (all figures except Figures 12, 13; $\times 250$ ) and acetate peels (Figures 12,$13 ; \times 210$ ).

Figures 1, 2 Crassicolaria brevis Remane.

1. Sample 416A-50-1, 25-27 cm.

2. Sample 416A-50-2, 11-15 cm.

Figures 3, 4 Crassicolaria intermedia (Durand Delga).

3. Sample 416A-47-1, 99-104 cm.

4. Sample 416A-50-1, 90-94 cm.

Figures 5-8 Tintinnopsella carpathica (Murgeanu and Filipescu).

5. Sample 416A-36-3, 23-25 cm.

6, 7. Sample 416A-37-4, 60-63 cm.

8. Sample 416A-51-1, 55-59 cm.

Figures 9-14 Lorenziella hungarica Knauer and Nagy.

9. Sample 416A-36-2, 94-96 cm.

10. Sample 416A-38-1, 127-132 cm.

11. Sample 416A-40-3, 3-6 cm.

12, 13. Sample 416A-41-4, 103-107 cm.

14. Sample $416 \mathrm{~A}-48-1,26-28 \mathrm{~cm}$.

Figures 15-18 Undifferentiated calpionellids.

15. Sample 416A-37-3, 29-31 cm.

16. Sample 416A-41-3, 111-112 cm.

17. Sample 416A-41-4, 103-106 cm.

18. Sample 416A-51-CC, 1-5 cm. 


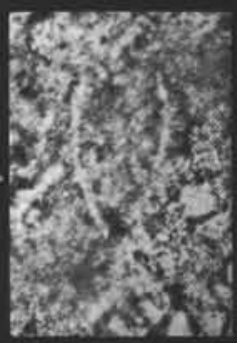

1

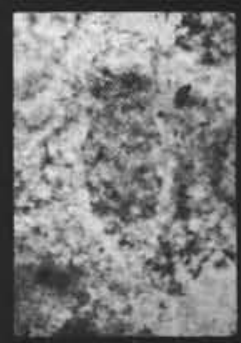

2

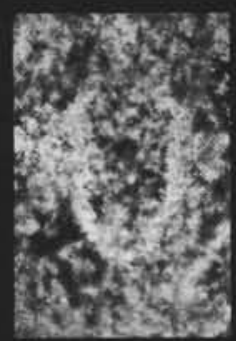

3

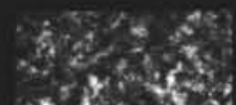
$\cos ^{2}+14,3$

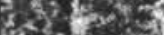
$x^{2} \times \cos ^{2}, 5$ Sathe 20 s.t.

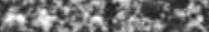
atovent?

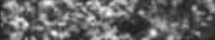

4

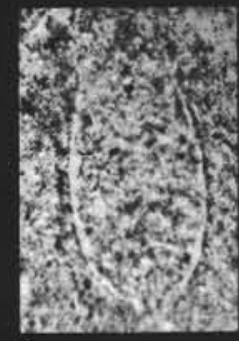

5

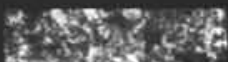

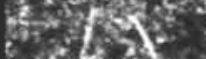 5.2tatis $\cot 5$ sर ares rateris 2800 .

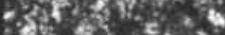 - $52 x+1$}

6

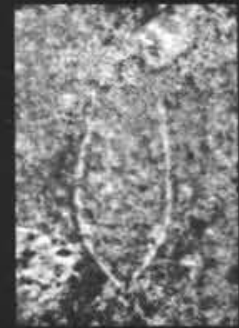

7

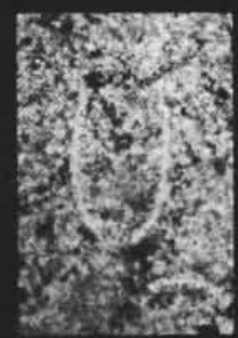

8

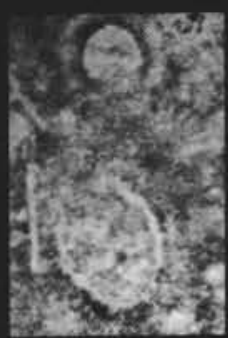

9

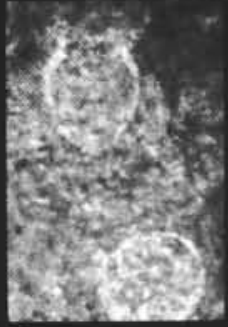

10

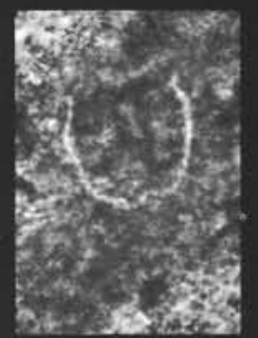

11

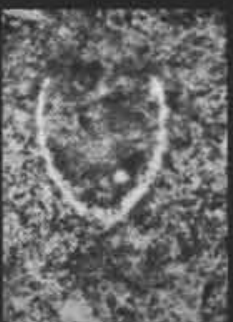

15

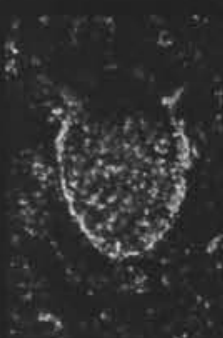

12

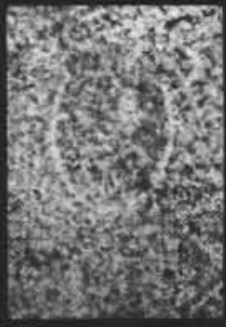

16

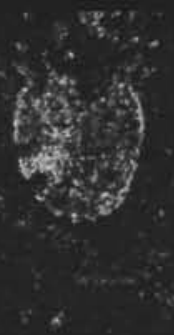

13

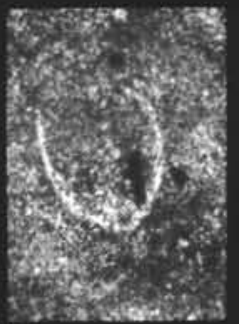

17

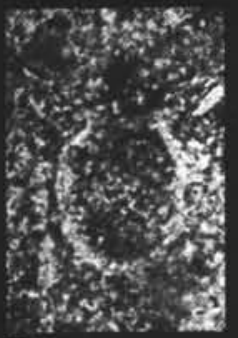

14 
PLATE 6

All figures are scanning electron micrographs.

Figures 1-12 Calpionella alpina Lorenz.

1. Sample 416A-29-5, 3-5 cm $(\times 603)$.

2 , 3. Sample 416A-30-3, 143-144 cm $(2 \times$ $603,3 \times 648)$.

4-7. Sample 416A-40-CC $(\times 648)$.

8, 9. Sample 416A-46-2, 64-66 cm ( $\times 648)$.

$10-12$. Sample 416A-46-4, 83-85 cm ( $\times 648)$.

Figures 13-15 Forms transitional between C. alpina and C. elliptica.

13, 14. Sample 416A-50-2, 6-9 cm ( $\times 603)$.

15. Sample 416A-40-CC $(\times 648)$. 

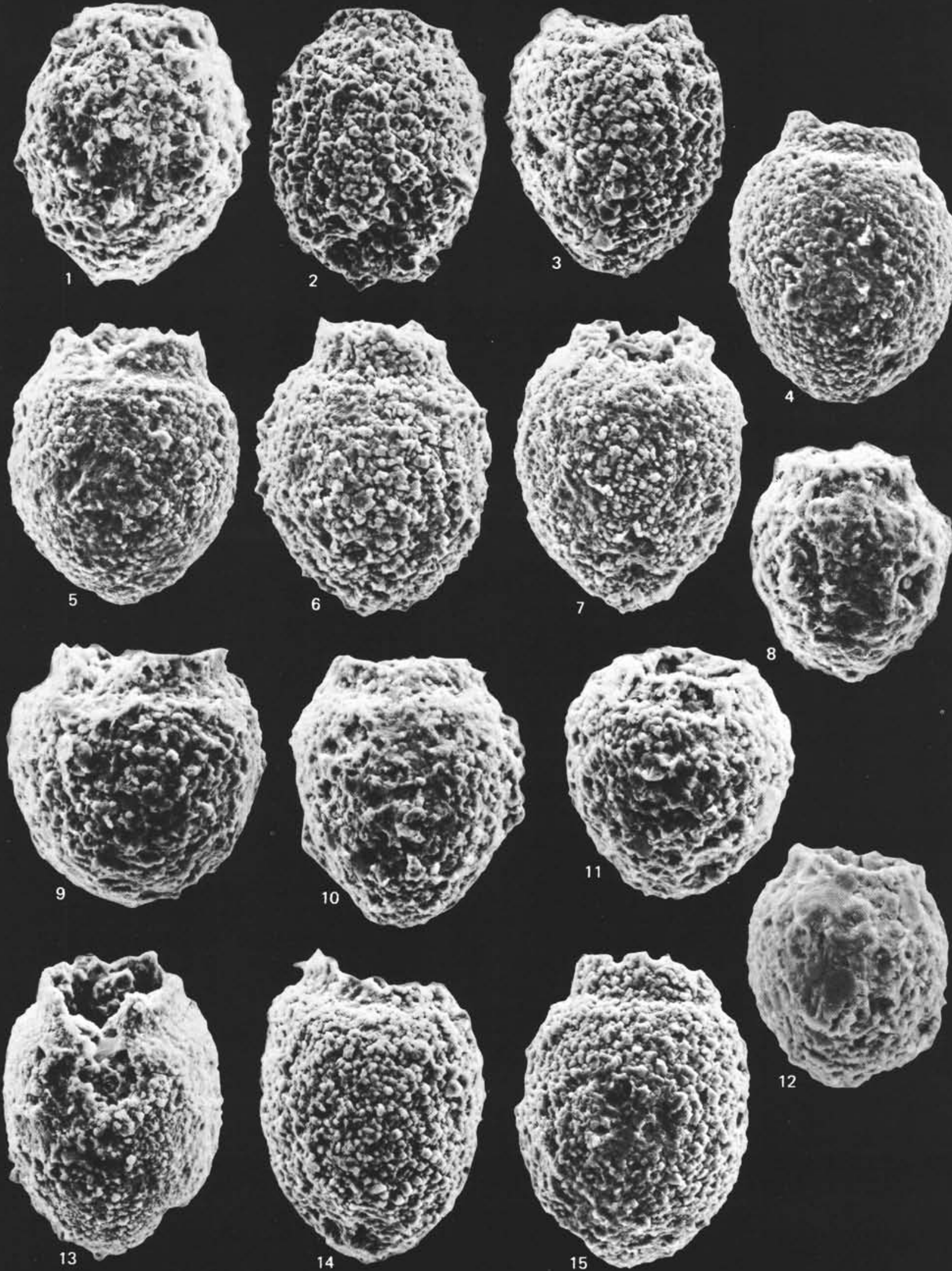
PLATE 7

All figures are scanning electron micrographs.

Figures 1-9 Remaniella sp. cf. $R$. cadischiana (Colom).

1. Sample 416A-30-3, 143-144 cm $(\times 600)$.

2-9. Sample 416A-52-3, 78-80 cm (2, 3, $6 \times$ $1000 ; 4,7, \times 1100 ; 5,8, \times 930 ; 9$, detail of lorica surface of $8, \times 3300$ ).

Figures 10, 11 Tintinnopsella sp. cf. T. carpathica (Murgeanu and Filipescu).

Sample 416A-29-5, 3-5 cm $(10, \times 500 ; 11$, detail of lorica surface of $10, \times 4600)$. 
PLATE 7

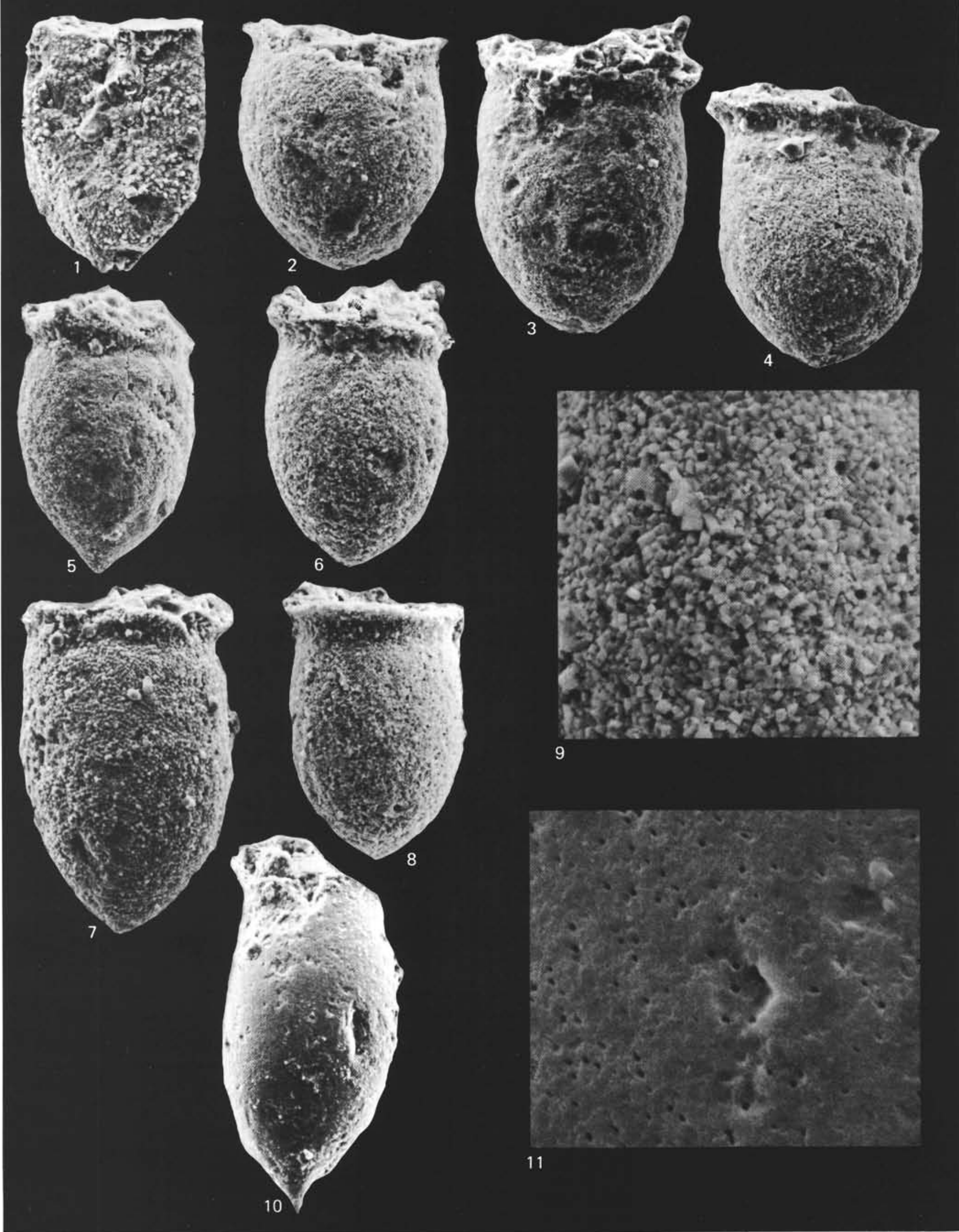


PLATE 8

All figures are scanning electron micrographs.

Figures 1-4 Tintinnopsella sp. cf. T. carpathica (Murgeanu and Filipescu).

1, 2. Sample 416A-30-3, 143-144 cm $(1, \times 830 ; 2$, detail of lorica surface, $\times 7600$ ).

3, 4. Sample 416A-46-2, 64-66 cm (3, $\times 460 ; 4$, $\times 530$ ).

Figures 5-7 ?Lorenziella $\mathrm{sp.}$

5. Sample 416A-40-4, 139-141 cm $(\times 660)$.

6 , 7. Sample 416A-40-CC $(\times 760)$.

Figures 8, 9 ? Calpionellites darderi (Colom). Sample 416A-40-CC $(\times 760)$. 


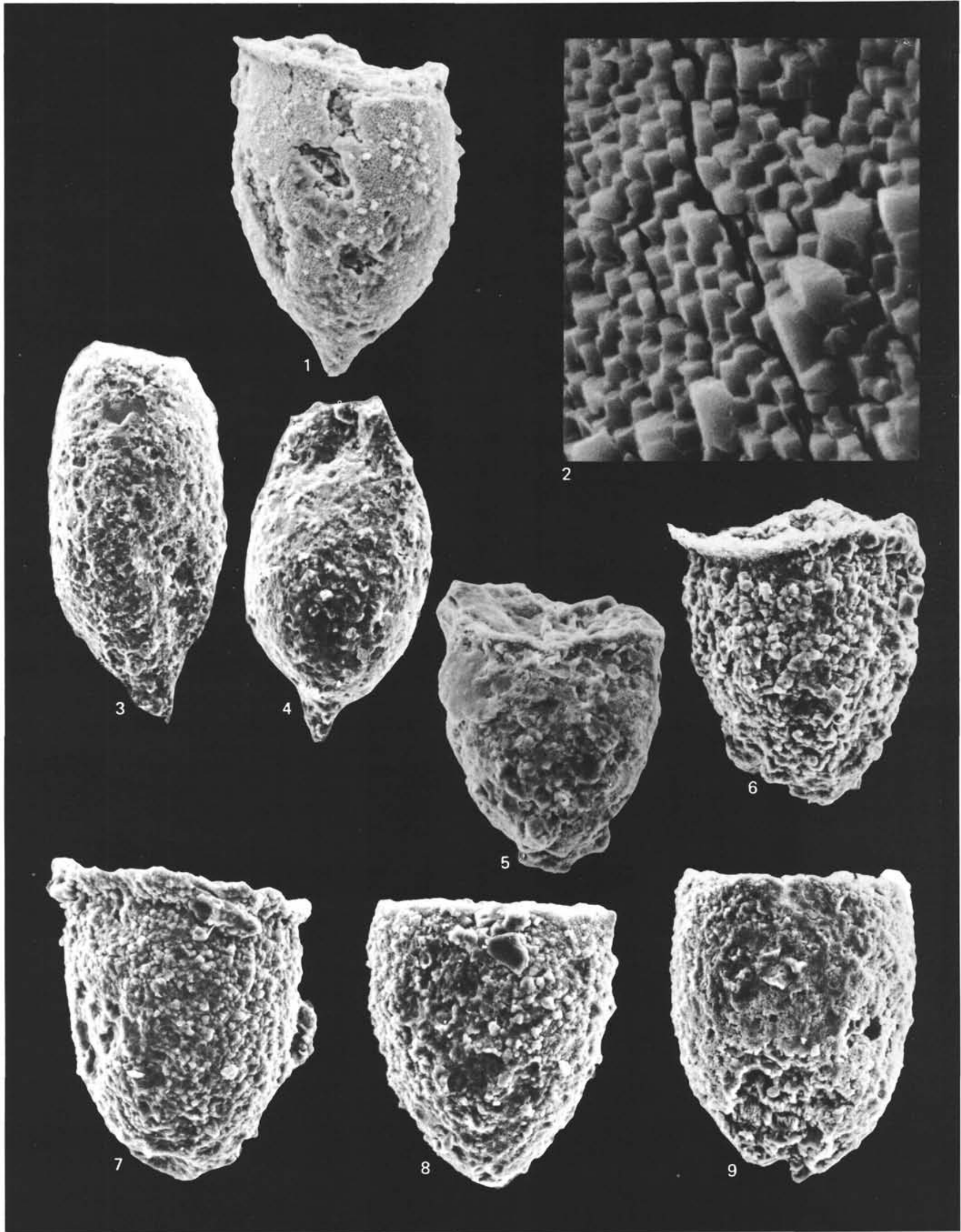


PLATE 9

All figures are light micrographs of strewn slides.

Figure $1 \quad$ Crassicolaria sp.

Sample 416A-51-1, 141-143 cm. (× 390).

Figures 2-4 Calpionella alpina Lorenz.

2. Sample 416A-39-CC $(\times 250)$.

3. Sample 416A-40-30, 86-88 cm ( $\times 380)$.

4. Sample 416A-41-3, 101-103 cm $(\times 390)$.

Figures 5-7 Forms transitional between C. alpina and C. elliptica.

5,6. Sample 416A-38-CC $(5, \times 335 ; 6, \times 390)$.

7. Sample 416A-43-CC $(\times 335)$.

Figure $8 \quad$ Calpionella elliptica Cadisch. Sample 416A-39-CC $(\times 390)$.

Figure 9 Tintinnopsella carpathica (Murgeanu and Filipescu).

Sample 416A-51-1, 141-143 cm ( × 335).

Figures 10-13 Remaniella sp. cf. R. cadischiana (Colom).

10. Sample 416A-38-CC $(\times 335)$.

11. Sample 416 A-39-CC $(\times 380)$.

12,13. Sample 416A-41-3, 101-103 cm ( $\times 390)$.

Figures 14, 15 Lorenziella hungarica Knauer and Nagy.

14. Sample 416A-39-CC $(\times 380)$.

15. Sample $416 \mathrm{~A}-41-3,101-103 \mathrm{~cm}(\times 380)$.

Figures 16-18 Undifferentiated calpionellids.

16. Sample 416A-38-CC $(\times 335)$.

17. Sample 416A-41-CC $(\times 390)$.

18. Sample 416A-51-1, 141-143 cm ( $\times 335)$. 

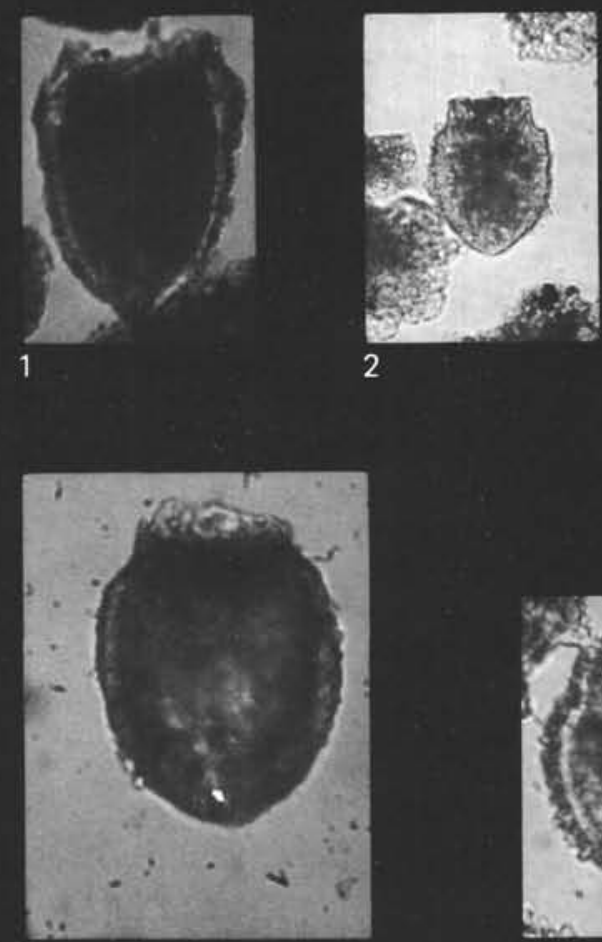

6
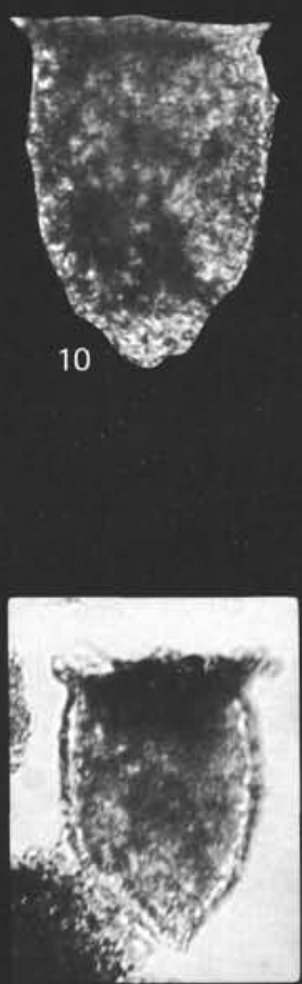

14

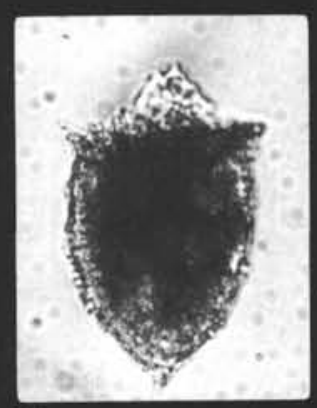

15
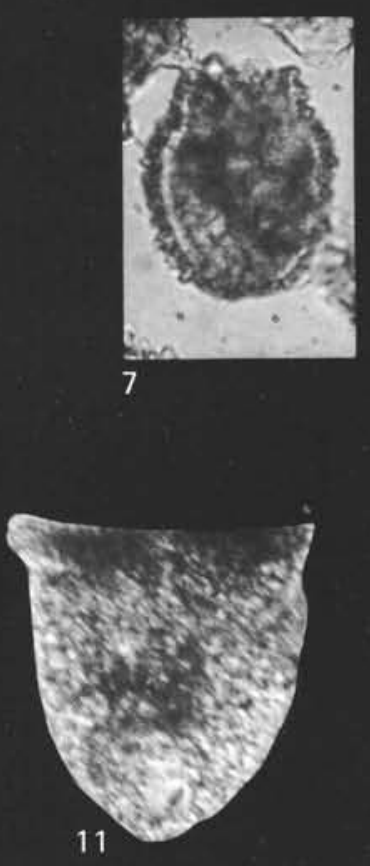
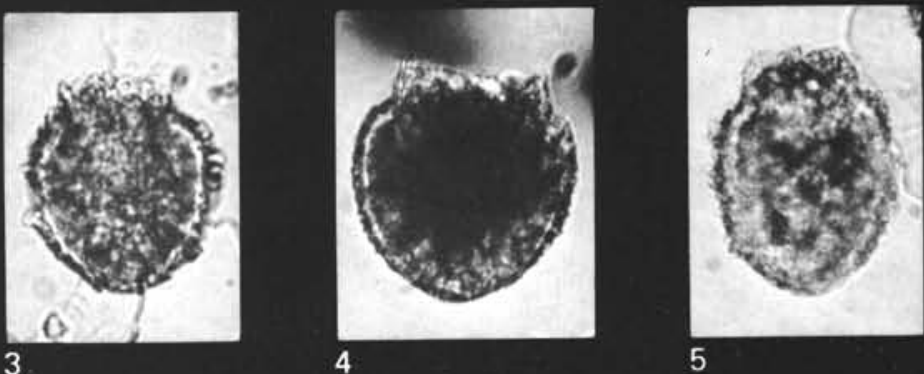

5

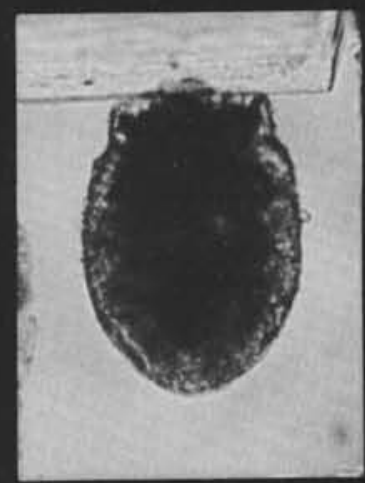

8

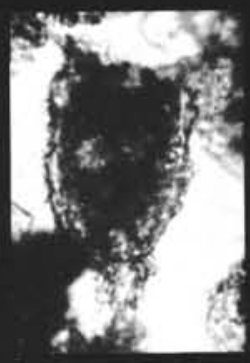

9
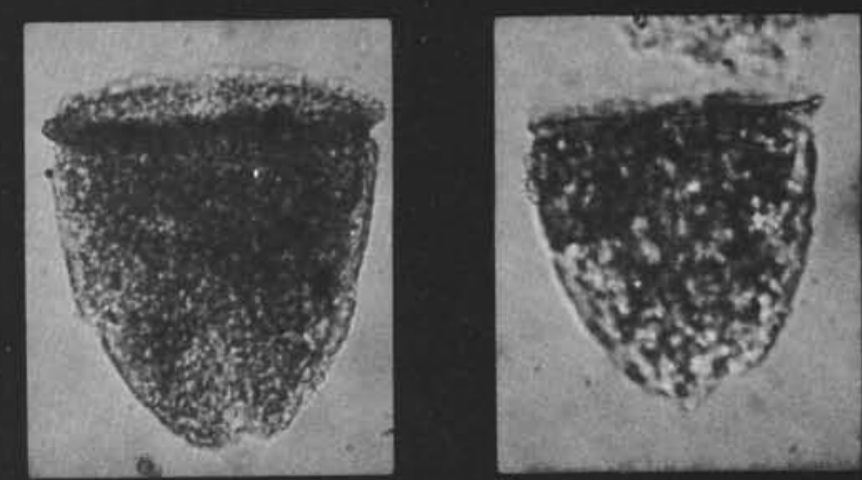

12

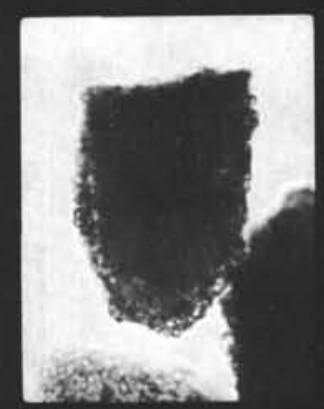

16

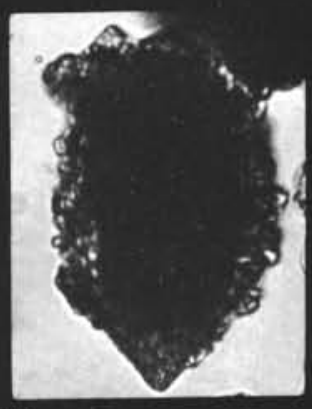

17

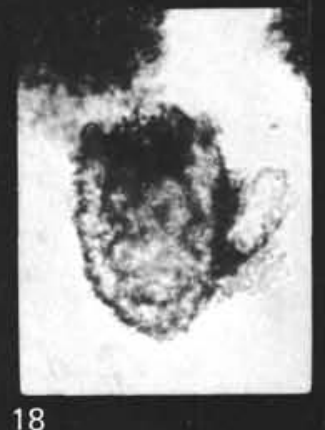

18 